Asian Pacific Journal of Reproduction

Journal homepage: www.apjr.net

\title{
Cervical dilation and improvement of reproductive performance in fat-tailed ewes
} via cervical dilator treatments

\author{
Reza Masoudi ${ }^{1 凶}$, Ahmad Zare Shahneh ${ }^{1}$, Armin Towhidi ${ }^{1}$, Hamid Kohram ${ }^{1}$, Abbas Akbarisharif ${ }^{2}$, Mohsen Sharafi ${ }^{3}$, \\ Mahdi Zhandi, MAMM Shahab-El-Deen ${ }^{4}$ \\ ${ }^{I}$ Department of Animal Science, University College of Agriculture and Natural Resources, University of Tehran, Karaj, Iran \\ ${ }^{2}$ The Breeding Station of Zandi Sheep, Pishwa, Varamin, Iran \\ ${ }^{3}$ Department of Poultry Science, Faculty of Agriculture, University of Tarbiat Modares. Tehran, Iran \\ ${ }^{4}$ Department of Animal Production, Faculty of Agriculture, Suez Canal University, Ismailia, Egypt
}

\section{ARTICLE INFO}

Article history:

Received 6 January 2017

Revision 12 Februay 2017

Accepted 20 February 2017

Available online 1 March 2017

Keywords:

Artificial insemination

Cervical dilators

Fat-tailed ewes

Reproductive performance

\begin{abstract}
Objective: To determine the effect of different cervical dilators on cervical dilation and reproductive performance of fat-tailed ewes. Methods: In experiment 1140 ewes were divided into seven groups with seven different treatments as following: $10 \mathrm{~mL}$ normal saline (control group), $100 \mathrm{IU}$ oxytocin (OT group), $100 \mu \mathrm{g}$ estradiol and $100 \mathrm{IU}$ oxytocin ( $\mathrm{E}_{2}+\mathrm{OT}$ group), $5 \mathrm{~mL}$ relaxin (R group), $2 \mathrm{~mL}$ sensiblex (SEN group), $200 \mu \mathrm{g}$ misoprostol (MIS group) or $200 \mu \mathrm{g}$ dinoprostone (DIN group). In experiment 2, artificial insemination was applied for evaluation of reproductive performance in experimental groups. Results: In experiment 1 , the highest cervical dilation was observed in OT $(90 \%)$ and $\mathrm{E}_{2}+\mathrm{OT}(100 \%)$ groups $(P<0.05)$, while no significant differences was found among DIN, MIS, SEN and R groups $(80 \%, 75 \%, 70 \%$ and $65 \%$, respectively). In addition, the lowest cervical dilation was observed in control group. Experiment 2 found no significant differences among control, OT and $\mathrm{E}_{2}+\mathrm{OT}$ groups. The highest pregnancy rate, parturition rate and lambing rate were observed in OT groups $(60 \%$, $60 \%$ and $70 \%$, respectively) and $\mathrm{E}_{2}+\mathrm{OT}$ groups $(65 \%, 60 \%$ and $70 \%$, respectively) compared to SEN, R, MIS and DIN groups $(P<0.05)$. Conclusions: Oxytocin treatment alone or with estradiol could be used as a suitable dilator for improving reproductive efficiency during artificial insemination in fat-tailed ewes.
\end{abstract}

\section{Introduction}

Artificial insemination (AI) in sheep is a valuable tool for amplification of good sire in commercial stock. Nowadays, AI uses fresh and frozen semen but with almost no satisfactory results. This phenomenon is mainly related to the winding shape of ewes' cervix and lack of efficient methods[1]. Although laparoscopy and laparotomy have been used as efficient methods for artificial, they have some limitations including high cost, time consuming and special equipment[2,3]. Therefore, changes in the physiological characteristics of cervix seem to be an efficient method to improve

\footnotetext{
Corresponding author: Dr. Reza Masoudi, Department of Animal Science, University College of Agriculture and Natural Resources, University of Tehran, Karaj,

Tel: +98 9122166375

E-mail: reza.masoodi@gmail.com; rezamasoudi@ut.ac.ir
} Iran. the reaching of sperm to fertilization site.

Cervix in ewes is a long fibrosis tubular structure containing around 5 rings[4]. According to the histological studies, the interior rings are the most important obstacle against insemination pipette[5]. To overcome this problem, two strategies have been recorded. The first one is a physico-mechanichal method[6] that is based on physical stress to the cervix or transfer of sperm by a flexible or semi-flexible pipette[6-10] that may injure the cervix and produce

This is an open access article distributed under the terms of the Creative Commons Attribution-Non Commercial-Share Alike 3.0 License, which allows others to remix, tweak and buid upon the work non-commercially, as long as the author is credited and the new creations are licensed under the identical terms.

For reprints contact: reprints@medknow.com

C2017 Asian Pacific Journal of Reproduction Produced by Wolters Kluwer- Medknow

How to cite this article: Reza Masoudi, Ahmad Zare Shahneh, Armin Towhidi, Hamid Kohram, Abbas Akbarisharif, Mohsen Sharafi, Mahdi Zhandi, MAMM Shahab-El-Deen. Cervical dilation and improvement of reproductive performance in fat-tailed ewes via cervical dilator treatments. Asian Pac J Reprod 2017; 6(2): 93-96. 
some anti-sperm secretions leading to lower sperm viability, and consequently lower conception rate[11,12]. In recent years, hormonal strategy has been proposed to improve the efficacy of AI. Oxytocin and prostaglandin E (PGE) are effective hormones on cervix dilation[8,13,14]. Oxytocin and $\mathrm{E}_{2}$ have no effects on luteal phase and have minimum injury when pipette is crossing the cervix during AI[8]. Oxytocin administration dilates the cervix and thus facilitates the passage of the pipette through the cervix and allow semen deposition intra uterus[8].

In our records, no attempt has been made to evaluate the efficacy on AI of the systematic comparison of oxytocin, estradiol and oxytocin, relaxin, sensiblex, misoprostol and dinoprostone. Furthermore, we applied AI technique for the first time to assess the effects of these treatments on the reproductive performances. Therefore, this study was conducted to determine the effect of different cervical dilators on cervical dilation and reproductive performance of fat-tailed ewes.

\section{Materials and methods}

\subsection{Experiments design}

One hundred forty Iranian fat-tailed Zandi ewes with $(55 \pm 5) \mathrm{kg}$ weight and 3 to 4-year-old were used to determine the effects of different cervical dilators on cervical dilation and reproductive performance.

\subsection{Experiment I}

All ewes received controlled internal drug release (CIDR) (EasyBreed $^{\mathrm{TM}}$, CIDR ${ }^{\circledR}$, New Zealand) for $12 \mathrm{~d}$. After CIDR removed about $2 \mathrm{~d}$, they were divided into 7 equal groups (20 ewes per group). Each group received one of the following treatments: 1) $10 \mathrm{~mL}$ saline (control group). 2) $100 \mathrm{IU}$ oxytocin (Abureihan Pharmacy; 10 IU/mL oxytocin, Iran) (OT group). 3) $100 \mu$ g estradiol (Abureihan pharmacy, $2 \mathrm{mg} / \mathrm{mL}$ estradiol benzoate, Iran) and 12 h later $100 \mathrm{IU}$ oxytocin ( $\mathrm{E}_{2}+\mathrm{OT}$ group). 4) $5 \mathrm{~mL}$ relaxin (Sina Pharmacy; 1 g/10 mL Methocarbamol, Iran) (R group). 5) $2 \mathrm{~mL}$ sensiblex (Veyx Pharma-GmbH; $40 \mathrm{mg} / \mathrm{mL}$ solution Denaverine hydrochloride) (SEN group). 6) $200 \mu \mathrm{g}$ misoprostol ( $\mathrm{PGE}_{1}$ analogue, Abureihan Pharmacy, Iran) (MIS group). 7) $200 \mu \mathrm{g}$ dinoprostone ( $\mathrm{PGE}_{2}$ analogue, Abureihan Pharmacy, Dinoproston, $\mathrm{PGE}_{2}$ analogue, Iran) (DIN group). The method, time and dosages of hormonal applications were used according the instruction of company and their effective time of each hormone, specifically (Table 1).

\subsection{Experiment II}

To evaluate the reproductive performance, ewes were intramuscularly received 500 IU eCG (Sanofi Animal Health, Libourne Cedex, France) at the time of CIDR removal and divided into 7 equal groups for $\mathrm{AI}$ according to Table 1. All ewes were inseminated $54 \mathrm{~h}$ after CIDR removal.
Table 1

Experimental procedure to determine the cervical dilators effects on cervical dilation and reproduction performance.

\begin{tabular}{|c|c|c|c|c|}
\hline Groups & Treatments & Dosage & $\begin{array}{l}\text { Cervicaldilation } \\
\text { measurement }\end{array}$ & $\mathrm{AI}$ \\
\hline 1 & Saline & $10 \mathrm{~mL}$ & $\begin{array}{l}20 \text { min after } \\
\text { injection }\end{array}$ & $\begin{array}{l}54 \mathrm{~h} \text { after CIDR } \\
\text { removal }\end{array}$ \\
\hline 2 & Oxytocin & $100 \mathrm{IU}$ & $\begin{array}{l}20 \text { min after } \\
\text { injection }\end{array}$ & $\begin{array}{l}20 \text { min after } \\
\text { injection }\end{array}$ \\
\hline 3 & $\begin{array}{l}\text { Estradiol/ } \\
\text { Oxytocin }\end{array}$ & $\begin{array}{l}100 \mu \mathrm{L} / \\
100 \mathrm{IU}\end{array}$ & $\begin{array}{l}20 \text { min after OT } \\
\text { injection }\end{array}$ & $\begin{array}{l}20 \text { min after OT } \\
\text { injection }\end{array}$ \\
\hline 4 & Relaxin & $5 \mathrm{~mL}$ & $\begin{array}{l}40 \text { min after } \\
\text { injection }\end{array}$ & $\begin{array}{l}40 \text { min after } \\
\text { injection }\end{array}$ \\
\hline 5 & Sensiblex & $2 \mathrm{~mL}$ & $\begin{array}{l}40 \text { min after } \\
\text { injection }\end{array}$ & $\begin{array}{l}40 \text { min after } \\
\text { injection }\end{array}$ \\
\hline 6 & Misoprostol & $200 \mu \mathrm{g}$ & $\begin{array}{l}5 \mathrm{~h} \text { after pessary } \\
\text { insertion }\end{array}$ & $\begin{array}{l}5 \mathrm{~h} \text { after pessary } \\
\text { insertion }\end{array}$ \\
\hline 7 & Dinoprostone & $200 \mu \mathrm{g}$ & $\begin{array}{l}5 \mathrm{~h} \text { after pessary } \\
\text { insertion }\end{array}$ & $\begin{array}{l}5 \mathrm{~h} \text { after pessary } \\
\text { insertion }\end{array}$ \\
\hline
\end{tabular}

\subsection{Cervix relaxation measurement}

Cervical dilation was measured by a scaled AI pipette $(40 \mathrm{~cm}$ length and $4 \mathrm{~mm}$ diameter). The difference in penetration before and after injections and pessary insertion in each group was considered as cervical penetration.

\subsection{Sperm collection and dilution}

Semen was collected using artificial vagina from six mature Zandi rams. To eliminate individual differences, the semen was pooled and then diluted 1:1 (v:v) with skim milk and finally loaded in straws $(0.25 \mathrm{~mL})$. Semen samples with at least $60 \%$ progressive motility was selected for insemination.

\subsection{AI and pregnancy diagnosis}

AI was transcervically accomplished at the time of cervical dilation, $54 \mathrm{~h}$ after CIDR removal. For control group, the routine method was applied for AI. Pregnancy diagnosis was performed by an ultrasound unit (falco 100, premedical) equipped with a $3.5 \mathrm{MHz}$ sectorial transducer probe in day 50 post insemination.

\subsection{Statistical analysis}

The SAS (9.1) GLM procedure were used to determine the effect of treatments on cervix dilation. When $F$-tests were significant, the DUNCAN option in GLM was used to separate means and reproductive parameters were analyzed via GENMOD procedure.

\section{Results}

\subsection{Experiment 1: Cervical dilation}

Table 2 shows the results of cervical dilation in ewes treated with various hormonal groups. Cervical dilation has been improved in OT, $\mathrm{E}_{2}+\mathrm{OT}$, DIN, MIS, SEN and R groups.

The highest rate of cervical dilation were observed in OT (90\%) 
Table 2

Effects of cervical dilator treatments on cervical dilation, and different cervical dilators on pregnancy, parituration, lambing and twinning rate of Iranian fat tailed Zandi ewes.

\begin{tabular}{lccccccc}
\hline Treatments & Control & OT & $\mathrm{E}_{2}+\mathrm{OT}$ & $\mathrm{R}$ & SEN & MIS & DIN \\
\hline Penetration $(\mathrm{cm})^{*}$ & 0.59 & $3.90^{*}$ & $4.10^{*}$ & $3.11^{*}$ & $3.28^{*}$ & $3.32^{*}$ & $3.56^{*}$ \\
Open Cervixes $(n)^{*}$ & $0 / 20$ & $18 / 20$ & $20 / 20$ & $13 / 20$ & $14 / 20$ & $15 / 20$ & $16 / 20$ \\
Open Cervixes (\%) & 0 & 90 & 100 & 65 & 70 & 75 & 80 \\
Pregnancy rate(\%) & $(10 / 20) 50$ & $(12 / 20) 60$ & $(13 / 20) 65$ & $(2 / 20) 10^{*}$ & $(2 / 20) 10^{*}$ & $(5 / 20) 25^{*}$ & $(6 / 20) 30^{*}$ \\
Parturition rate (\%) & $(9 / 20) 45$ & $(12 / 20) 60$ & $(12 / 20) 60$ & $(1 / 20) 5^{*}$ & $(2 / 20) 10^{*}$ & $(4 / 20) 20^{*}$ & $(4 / 20) 20^{*}$ \\
Lambing rate (\%) & $(10 / 20) 50$ & $(14 / 20) 70$ & $(14 / 20) 70$ & $(1 / 20) 5^{*}$ & $(2 / 20) 10^{*}$ & $(4 / 20) 20^{*}$ & $(4 / 20) 20^{*}$ \\
Twinning rate $(\%)$ & $(1 / 9) 11.11$ & $(2 / 12) 16.66$ & $(2 / 12) 16.66$ & $(0 / 1) 0$ & $(0 / 2) 0$ & $(0 / 4) 0$ & $(0 / 4) 0$ \\
\hline
\end{tabular}

The number in parentheses indicates the number of ewes/total in each group. " $P<0.05$ compared with control group. R: Relaximol, SEN: Sensiblex, MIS: Misoprostol, DIN: Dinoproston. "SEM=0.19.

and $\mathrm{E}_{2}+\mathrm{OT}(100 \%)$ groups $(P<0.05)$. In pairwise comparison on OT and $\mathrm{E}_{2}+\mathrm{OT}$ groups, no significant difference was observed between them. Furthermore, no significant differences were observed among DIN, MIS, SEN and R groups $(80 \%, 75 \%, 70 \%$ and $65 \%$, respectively), and their rate of cervical dilation were lower than OT and $\mathrm{E}_{2}+\mathrm{OT}$ groups'. Saline had no effect on cervical dilation.

\subsection{Experiment 2: Reproduction performance}

Table 2 shows the percentage of reproductive performance traits of ewes treated with different cervical dilators. OT and $\mathrm{E}_{2}+\mathrm{OT}$ treatments have improved pregnancy rate $(60 \%$ and $65 \%$, respectively) compared to R (10\%), SEN (10\%), MIS (25\%) and DIN $(30 \%)$ groups $(P<0.05)$. Pregnancy rate was not significantly higher in $\mathrm{OT}$ and $\mathrm{E}_{2}+\mathrm{OT}$ groups compared to control group. Moreover, there were no significant differences between OT group and $\mathrm{E}_{2}+\mathrm{OT}$ group. The pregnancy rate of R, SEN, MIS and DIN groups was lower than control group $(P<0.05)$. Group OT and $\mathrm{E}_{2}+\mathrm{OT}(60 \%)$ have similar parturition rate, which was the highest one in comparison to other groups' (R: 5\%, SEN: 10\%, MIS: $20 \%$ and DIN: 20\%). However, parturition rates of R, SEN, MIS, and DIN groups were lower than control group (45\%).

OT or $\mathrm{E}_{2}+\mathrm{OT}$ treatment led to significant improvement in lambing rate, which was $70 \%$ in comparison to groups R (5\%), SEN (10\%), MIS $(20 \%)$, and DIN $(20 \%)(P<0.05)$. However, there were no significant differences among OT, $\mathrm{E}_{2}+\mathrm{OT}$ and control groups in lambing rate. Lambing rate in R, SEN, MIS, and DIN groups was significantly lower than control groups $(P<0.05)$.

\section{Discussion}

The deeper intra cervix insemination in ewes allows more spermatozoa to reach fertilization site and subsequently increase the fertilization rate, and ultimately improve pregnancy rates[15,16]. However, unique structure of ewes' cervix acts as a barrier against AI gun and embryo recovery catheter which causes drooping of fertility rates following AI and embryo transfer[8]. Hormonal treatment to change the physiological characteristics of cervix seems to be an efficient method for increment of sperm chance for fertilization. Misoprostol pessary which used $48 \mathrm{~h}$ after sponge removal led to cervix opening in $100 \%$ of ewes at the time of $\mathrm{AI}[17]$. In this study, using misoprostol and dinoprostone could make cervical dilation and penetration of insemination gun into uterus of $75 \%$ and $80 \%$ ewes. However, the lambing rate in these groups was lower compared to OT, ET+OT and control group.

Furthermore, relaxin treatment did not have beneficial effects on reproductive parameters. Similarly, Akinbami et al.[18] observed that oocyte recovery rate and pregnancy rate of ewes with relaxin treatment was depressed, mainly because relaxin causes uterus and cervix to unclench too much that hampers sperm oocyte interaction. Hence, low fertilization rate might explain the lower lambing rate of $\mathrm{R}(5 \%)$ and SEN (10\%) in our study.

Among various cervical dilators, OT and $\mathrm{E}_{2}+\mathrm{OT}$ had the highest significant rate of pregnancy, parturition rate and lambing rate compared to other groups. This answer may be explained by effects of oxytocin that initiates collagenolytic enzyme process resulting in cervical dilation[19]. Previous studies showed that $\mathrm{E}_{2}+\mathrm{OT}$ or only OT[13,20-22] caused cervical dilation in ewes. It has been proven that 400 IU OT led to dilation of cervix, but the injection of this amount of hormone right before the insemination may have some problems. In this study, 100 IU OT increased dilation of the cervix successfully, which reduced the cost of cervical dilation treatment. It has been previously proven that $\mathrm{E}_{2}+\mathrm{OT}$ have no negative effects on luteal activity. Meanwhile, their application reduces the cervix damage during insemination and transcervical embryo transfer, and increase the functional speed during embryo recovery[8,23]. Estradiol enhances the effect of OT through increasing OT receptors and improving cell responsiveness to OT. Estradiol up-regulates cyclooxygenase mRNA and EP4 expression in cervix, and may cause cervical dilation by either increasing the production of $\mathrm{PGE}_{2}$ or activating its receptors. After $\mathrm{E}_{2}$ injection for 24-28 h, it has been shown that the amount of cyclooxygenase gene expression increased[24]. Moreover, oxytocin increases uterine constrictions with no deleterious effects on sperm transfer into the oviduct. The minimum dosage needed for dilating the cervix is $50 \mathrm{IU}[12]$. Also, $\mathrm{PGE}_{2}$ remodels the extracellular matrix of the cervix which ultimately lead to the process of cervical dilation[25,26]. $\mathrm{PGE}_{2}$ exerts its action mainly through the expansion of smooth muscle and increasing the production of glycosaminogly can by activating EP4 and EP2 receptors in the cervix. Hyaluronan and water molecules accumulation between collagen fibrils could lead to dispersion of collagen fibrils, which reduces the cervix resistance[27]. On the other hand, low molecular weight of hyaluronan affects vascularization, increases leukocytes penetration and stimulates cervix biochemical changes[28]. As leukocytes accumulate in the cervix, the neutrophils contain excessive amount of collagenase 
and elastase, which are important for collagen fibrils dispersion and cervical dilation.

Furthermore, OT could increase sperm transfer through the female reproductive tract[29] and consequently more spermatozoa arrive to fertilization site. Moreover, OT injection during estrus elevate ovulation rate[30] so that the rate of sperm/oocyte fertilization increases.

From the results of our study, it could be concluded that $\mathrm{E}_{2}+\mathrm{OT}$ causes cervical dilation in Zandi ewes, which provides possibility of non-surgical intrauterine AI through cervix in ewes. Besides, the results of fertility traits showed that $\mathrm{E}_{2}+\mathrm{OT}$ treatment improves pregnancy, parturition and lambing rates of ewes.

\section{Conflict of interest statement}

We declare that we have no conflict of interest.

\section{References}

[1] Salamon S, Maxwell WMC. Frozen storage of ram semen I. Processing, freezing, thawing and fertility after cervical insemination. Anim Reprod Sci 1995; 37(3): 185-249.

[2] Evans G, Maxwell WMC. Salmon's artificial insemination of sheep and goats. UK: Butterworths; 1987.

[3] Torres S, Sevellec C. Repeated superovulation and surgical recovery of embryos in ewe. Reprod Nutr Dev 1987; 27(4): 859-863.

[4] Halbert GW, Dobson H, Walton JS, Buckrell BC. The structure of the cervical canal of the ewe. Theriogenology 1990; 33(5): 977-992.

[5] Kershaw CM, Khalid M, McGowan MR, Ingram K, Leethongdee S, Wax G, et al. The anatomy of the sheep cervix and its influence on the transcervical passage of an inseminating pipette into the uterine lumen. Theriogenology 2005; 64(5): 1225-1235.

[6] Halbert GW, Dobson H, Walton JS, Buckrell BC. A technique for transcervical intrauterine insemination of ewes. Theriogenology 1990; 33(5): 993-1010.

[7] Buckrell BC, Buschbeck C, Gartley CJ, Kroetsch T, McCutcheon W, Martin J, et al. Further development of a transcervical technique for artificial insemination in sheep using previously frozen semen. Theriogenology 1994; 42(4): 601-611.

[8] Wulster-Radcliffe MC, Costine BA, Lewis GS. Estradiol-17 betaoxytocin-induced cervical dilation in sheep: Application to transcervical embryo transfer. J Anim Sci 1999; 77(10): 2587-2593.

[9] Wulster-Radcliffe MC, Lewis GS. Development of a new transcervical artificial insemination method for sheep: Effects of a new transcervical artificial insemination catheter and traversing the cervix on semen quality and fertility. Theriogenology 2002; 58(7): 1361-1371.

[10]Wulster-Radcliffe MC, Wang S, Lewis GS. Transcervical artificial insemination in sheep: Effects of a new transcervical artificial insemination instrument and traversing the cervix on pregnancy and lambing rates. Theriogenology 2004; 62(6): 990-1002.

[11]Hawk HW. Sperm survival and transport in the female reproductive tract. J Dairy Sci 1983; 66(12): 2645-2660.

[12]Sayre BL, Lewis GS. Fertility and ovum fertilization rate after laparoscopic or transcervical intrauterine artificial insemination of oxytocin-treated ewes. Theriogenology 1997; 48(2): 267-275.
[13]Khalifa RM, Sayre BL, Lewis GS. Exogenous oxytocin dilates the cervix in ewes. J Anim Sci 1992; 70(1): 38-42.

[14]Mylne MJ, McKelvey WA, Fernie K, Matthews K. Use of a transcervical technique for embryo recovery in sheep. Vet Rec 1992; 130(20): 450-451.

[15]Eppleston J, Salamon S, Moore NW, Evans G. The depth of cervical insemination and site of intrauterine insemination and their relationship to the fertility of frozen-thawed ram semen. Anim Reprod Sci 1994; 36(3-4): 211-225.

[16]Anel L, Alvarez M, Martinez-Pastor F, Garcia-Macias V, Anel E, de Paz P. Improvement strategies in ovine artificial insemination. Reprod Domest Anim 2006; 2: 30-42.

[17]Leethongdee S, Khalid M, Bhatti A, Ponglowhapan S, Kershaw CM, Scaramuzzi RJ. The effects of the prostaglandin E analogue Misoprostol and follicle-stimulating hormone on cervical penetrability in ewes during the peri-ovulatory period. Theriogenology 2007; 67(4): 767-777.

[18]Akinbami MA, Meredith S, Warren JE Jr, Anthony RV, Day BN. Cervical dilation, conception rate, and concentrations of progesterone and estradiol-17B in postpartum ewes treated with porcine relaxin. Theriogenology 1990; 34(5): 927-940.

[19]Granström L, Ekman G, Ulmsten U, Malmstrom A. Changes in the connective tissue of corpus and cervix uteri during ripening and labour in term pregnancy. Br J Obstet Gynaecol 1989; 96(10): 1198-1202.

[20]Masoudi R, Shahneh AZ, Towhidi A, Kohram H, Akbarisharif A, Sharafi M. Fertility response of artificial insemination methods in sheep with fresh and frozen-thawed semen. Cryobiology 2017; 74: 77-80.

[21]Masoudi R, Kohram H, Shahne AZ, Davoud SDMA, Sharif AA. Effects of exogenous oxytocin on cervical penetration of Iranian ewes. Afr $J$ Biotechnol 2012; 11(9): 2398-2401.

[22]Masoudi R, Kohram H, Shahne AZ, Davoud SD. Effect of estradiol and oxytocin on ovine cervical relaxation. Afr J Biotechnol 2012; 11(11): 2803-2806.

[23]Stellflug JN, Wulster-Radcliffe MC, Hensley EL, Cowardin EA, Seals RC, Lewis GS. Oxytocin-induced cervical dilation and cervical manipulation in sheep: Effects on laparoscopic artificial insemination. $J$ Anim Sci 2001; 79(3): 568-573.

[24]Kershaw-Young CM, Scaramuzzi RJ, McGowan MR, Pitsillides AA, Wheeler-Jones CP, Khalid M. The effect of estradiol on COX-2, EP2, and EP4 mRNA expression and the extracellular matrix in the cervix of the hypogonadotrophic, ovariectomized ewe. Theriogenology 2010; 73(5): 620-628.

[25]Stys SJ, Dresser BL, Otte TE, Clark LE. Effect of prostaglandin $\mathrm{E}_{2}$ on cervical compliance in pregnant ewes. Am J Obstetr Gynecol 1981; 140(4): 415-419.

[26]Ledger WL, Elwood DL, Taylor MJ. Cervical softening in late pregnant sheep by infusion of prostaglandin $\mathrm{E}_{2}$ into cervical artery. J Reprod Fertil 1983; 69(2): 511-515.

[27]El Mardani E, Kanayama N, Kobayashi H, Hossain B, Khatun S, Liping $\mathrm{S}$, et al. The role of hyaluronic acid as a mediator and regulator of cervical ripening. Hum Reprod 1997; 12(5): 1080-1088.

[28]Perry K, Haresign W, Wathes DC, Khalid M. Intracervical application of hyaluronan improves cervical relaxation in the ewe. Theriogenology 2010; 74(9): 1685-1690.

[29]Ayad VJ, Leung ST, Parkinson TJ, Wathes DC. Coincident increases in oxytocin receptor expression and EMG responsiveness to oxytocin in the ovine cervix at oestrus. Anim Reprod Sci 2004; 80(3-4): 237-250.

[30]King PR, Coetzer WA. Effect of oxytocin treatment during oestrus on the ovulation rate of merino ewes. J S Afr Vet Assoc 1996; 67(1): 42-43. 